\title{
KINERJA BIDAN DESA DALAM DETEKSI DINI KASUS MALARIA PADA KEHAMILAN DI KABUPATEN BENGKULU TENGAH
}

\author{
Afrina Mizawati ${ }^{1}$, Mohammad Hakimi ${ }^{2}$, Hari Kusnanto ${ }^{3}$
}

\begin{abstract}
Background: Malaria has become the health problem that cause mortality especially in high risk group such as infants, children below 5 years old and pregnant women. The incidence of malaria in Central Bengkulu, Bengkulu Province is quite high, the last three years there is an increase compared to year 2011 - 2013. Annual Malaria Incidence in 2011 was 75.68/00, where the incidence in 2012 was 66.13/00. The Annual Parasite Incidence in 2013 was 52.34/00. In 2013, the amount of pregnant women who underwent malaria screening during 1st antenatal care (K1) only 784 from 2016 pregnant women(39\%).

Objective: To understand the malaria screening achievement among pregnant women by village midwives in Central Bengkulu District.

Method: The study was observational with cross sectional design. The subjects was all of the village midwives in Central Bengkulu District. The dependent variable in this study was midwives achievement in malaria screening during pregnancy. The independent variables were training for malaria screening during pregnancy and the availability of rapid diagnostic test (RDT). The disturbing variables were age, level of education, and the duration of work. The study's instrument was questionnare and observational sheet. The data analysis was done with t test, correlation method, chi square and linear regression.

Result and Discussion: The achievement in malaria's screening during pregnancy by village midwives was better in the group who received training compared with the group who didn't (RR $2.2 ; 95 \% \mathrm{Cl} 1.71-$ 2.51). The achievement also was better in the group of midwives who had good supply of RDT compared with the group who didn't (RR 1.5; 95\% Cl $1.01-1.94$ ).

Conclusion: The achievement of malaria's screening during pregnancy among village midwives who received training was better compared to midwives who didn't. The achievement was also better among midwives who had good supply of RDT compared with midwives who didn't. There is relation between level of midwivery education and the achievement in screening $b$ ut there was no relation between age and duration of work and achievement during screening.
\end{abstract}

Keywords: Achievement of Village Midwives, Screening, Training and Availability of RDT

\begin{abstract}
ABSTRAK
Latar Belakang: Malaria merupakan satu masalah kesehatan yang dapat menyebabkan kematian terutama kelompok risiko tinggi yaitu bayi, anak balita dan ibu hamil. Angka kejadian malaria di Bengkulu Tengah Provinsi Bengkulu cukup tinggi. Kejadian malaria di Kabupaten Bengkulu Tengah dalam 3 tahun terakhir mengalami peningkatan dari tahun 2011-2013. Annual Malaria Incidence tahun 2011 sebesar 75,68/00 positif, Annual Malaria Incidence tahun 2012 66,13/00 dan Annual Parasite Incidence 1,440/00 penderita positif dan Annual Malaria Incidence tahun 2013 sebesar 52,34/00. Pada tahun 2013 jumlah ibu hamil yang dilakukan skrining malaria pada kunjungan K1 pemeriksaan kehamilan hanya mencapai 784 dari 2016 ibu hamil (39\%).
\end{abstract}

Jurusan Kebidanan Poltekkes Kemenkes Bengkulu, Propinsi Bengkulu

2. Minat KIA-Kespro Fakultas Kedokteran UGM 
Tujuan: Untuk mengetahui gambaran kinerja deteksi dini kasus malaria pada kehamilan oleh bidan desa di Kabupaten Bengkulu Tengah

Metode: Jenis penelitian observasional dengan rancangan cross sectional. Subjek penelitian semua bidan desa di wilayah kerja Kabupaten Bengkulu Tengah. Variabel terikat dalam penelitian ini yaitu kinerja bidan desa dalam deteksi dini malaria pada kehamilan. Variabel bebas adalah pelatihan dan ketersediaan rapid diagnostic test. Variabel luar: usia, pendidikan dan masa kerja. Instrument penelitiannya adalah kuesioner dan lembar observasi. Analisis data terdiri dari analisis univariabel, bivariabel, dan multivariabel dengan uji t-test, korelasi, chi-square dan regresi linear.

Hasil dan Pembahasan: Kinerja deteksi dini kasus malaria kehamilan pada bidan desa yang telah dilatih lebih baik daripada bidan desa yang belum dilatih dengan perbedaan rerata 2,2 (95\% Cl 1,71-2,51) dan kinerja deteksi dini kasus malaria kehamilan pada bidan desa dengan ketersediaan RDT cukup lebih baik daripada bidan desa dengan ketersediaan RDT tidak cukup yaitu dengan perbedaan rerata 1,5 (95\% Cl 1,01-1,94)

Kesimpulan: Kinerja deteksi dini kasus malaria kehamilan pada bidan desa yang telah dilatih lebih baik daripada bidan desa yang belum dilatih, kinerja deteksi dini kasus malaria kehamilan pada bidan desa dengan ketersediaan RDT cukup lebih baik daripada bidan desa dengan ketersediaan RDT cukup. Ada hubungan pendidikan dengan kinerja bidan desa dalam deteksi dini kasus malaria kehamilan, tetapi tidak ada hubungan umur dan masa kerja dengan kinerja bidan desa dalam deteksi dini kasus malaria kehamilan

Kata Kunci: Kinerja Bidan Desa, Deteksi Dini, Pelatihan dan Ketersediaan RDT

\section{PENDAHULUAN}

Hasil pembangunan kesehatan saat ini adalah derajat kesehatan masyarakat semakin meningkat secara bermakna, namun belum dapat dinikmati secara merata oleh masyarakat dan masih belum tercapai semua. Pembangunan kesehatan memerlukan keterlibatan dari semua elemen yang ada baik pemerintah, swasta, dan masyarakat sipil. ${ }^{1}$ Pembangunan kesehatan pada masa ini lebih dititikberatkan pada tingkat desa sebagai unit terkecil utama dalam sistem pemerintahan. Desa mandiri sehat merupakan salah satu bentuk upaya strategis dalam rangka pencapaian tujuan pembangunan milenium (MDGs). Tujuan tersebut terutama yang berkaitan dengan aspek kesehatan yaitu menurunkan AKI dan AKB, meningkatan kesehatan ibu, memerangi HIV/AIDS, Malaria dan penyakit lainnya serta melestarikan lingkungan. ${ }^{2}$

Malaria merupakan penyakit menular yang sangat dominan di daerah tropis dan sub-tropis dan dapat mematikan. Penatalaksanaan malaria pada kehamilan menjadi tugas pokok yang dilaksanakan oleh bidan desa yang bertugas di desa. Data di Kabupaten Bengkulu Tengah menunjukkan skrining malaria pada kunjungan K1 pemeriksaan kehamilan hanya mencapai 784 orang ibu hamil $39 \%{ }^{3}$

Rendahnya cakupan skrining malaria pada kehamilan ini selain menunjukkan masih rendahnya kinerja bidan desa dalam melakukan deteksi dini malaria pada kehamilan. Hal ini juga disebabkan karena masih kurangnya ketersediaan alat diagnosis cepat (rapid diagnostic test/ RDT) yang akan digunakan dalam pemeriksaan deteksi dini malaria pada kehamilan. Berdasarkan data laporan tahunan program malaria Dinas Kesehatan Kabupaten Bengkulu Tengah Tahun 2013, hanya tersedia 2.000 buah alat diagnosis cepat (rapid diagnostic test/ RDT), dan jumlah tersebut tidak hanya digunakan bagi ibu hamil, tetapi juga untuk pasien lain diluar ibu hamil. 
Dari berbagai fakta menarik yang telah diuraikan di atas terdapat masalah yang berhubungan dengan kinerja bidan desa dalam deteksi dini kasus malaria pada kehamilan yaitu sebagai berikut: 1 ) belum semua bidan desa dilatih; 2) ketersediaan rapid diagnostic test tidak mencukupi sasaran.

\section{METODE}

Jenis penelitian ini adalah observasional dengan rancangan cross sectional dan pendekatan kuantitatif. Lokasi penelitian di wilayah kerja Dinas Kesehatan Kabupaten Bengkulu Tengah. Populasi dan sampel ini adalah semua bidan desa yang bertugas di wilayah Kabupaten Bengkulu Tengah pada tahun 2014 yang berjumlah 145 orang dan berdasarkan perhitungan jumlah sampel tersebut dengan menggunakan software PASS 2008 didapatkan power lebih dari $80 \%$.
Variabel dalam penelitian ini meliputi variabel bebas yaitu pelatihan tata laksana kasus malaria pada kehamilan dan ketersediaan rapid diagnostic test, variabel terikat adalah kinerja bidan desa dalam deteksi dini malaria pada kehamilan dan variabel luar adalah umur, pendidikan dan masa kerja bidan.

Penelitian ini menggunakan data primer yang diukur langsung oleh peneliti menggunakan lembar kuesioner dan lembar observasi yang merujuk dari Pedoman Penatalaksanaan Kasus Malaria Direktorat Jendral Pengendalian Penyakit dan Penyehatan Lingkungan Kemenkes RI 2011 yang telah dimodifikasi oleh penulis. Analisis data yang dilakukan adalah analisis univariabel, bivariabel dan multivariabel. Uji yang digunakan adalah t-test, korelasi, chi-square dan regresi linear.

\section{HASIL DAN PEMBAHASAN}

\section{Karakteristik Subjek Penelitian}

Distribusi karakteristik dari subyek penelitian ini dapat dilihat pada tabel berikut ini :

Tabel 1. Karakteristik bidan desa berdasarkan pelatihan, ketersediaan RDT pendidikan, umur dan masa kerja di Kabupaten Bengkulu Tengah

\begin{tabular}{|c|c|c|c|c|}
\hline \multirow{2}{*}{ Variabel } & \multicolumn{2}{|c|}{ Jumlah Bidan Desa } & \multirow{2}{*}{ Mean \pm SD } & \multirow{2}{*}{ Min-Max } \\
\hline & $n$ & $\%$ & & \\
\hline \multicolumn{5}{|l|}{ Pelatihan } \\
\hline Pernah & 47 & 32,4 & & \\
\hline Belum Pernah & 98 & 67,6 & & \\
\hline \multicolumn{5}{|c|}{ Ketersediaan RDT } \\
\hline Cukup & 48 & 33,1 & & \\
\hline Tidak Cukup & 97 & 66,9 & & \\
\hline \multicolumn{5}{|l|}{ Pendidikan } \\
\hline Tinggi & 95 & 65,5 & & \\
\hline Rendah & 50 & 34,5 & & \\
\hline \multicolumn{5}{|l|}{ Umur } \\
\hline 20-30 tahun & 91 & 62,8 & $28,5 \pm 3,84$ & $21-38$ \\
\hline 31-40 tahun & 54 & 37,2 & & \\
\hline \multicolumn{5}{|l|}{ Masa kerja } \\
\hline 1-7 tahun & 106 & 73,1 & $6,4 \pm 2,83$ & $1-14$ \\
\hline 8-14 tahun & 39 & 26,9 & & \\
\hline
\end{tabular}


Sebagian besar bidan belum pernah mengikuti pelatihan tata laksana kasus malaria kehamilan $(67,6 \%)$ dan tidak memiliki ketersediaan RDT yang cukup (66,9\%). Dari seluruh bidan desa yang ada sebagian besar memiliki pendidikan yang tinggi dengan umur paling banyak direntang 20-30 tahun dengan rata-rata umur 28 tahun dan mempunyai masa kerja paling banyak di rentang 1-7 tahun dengan rata-rata masa kerja 6 tahun.

Tabel 2. Rerata skor kinerja bidan desa di Kabupaten Bengkulu Tengah

\begin{tabular}{cccc}
\hline Variabel & $\mathrm{n}$ & Mean \pm SD & Min-Max \\
\hline Kinerja & 145 & $9,7 \pm 1,50$ & $7-12$ \\
\hline
\end{tabular}

Pada tabel diatas didapatkan bahwa rerata kinerja bidan desa dalam deteksi dini kasus malaria kehamilan di Kabupaten BengkuluTengah yaitu sebesar 9,7 dengan skor minimal 7 dan skor maksimal 12, artinya kinerja bidan desa dalam deteksi dini kasus malaria kehamilan di Kabupaten Bengkulu Tengah mempunyai skor rata-rata sebesar 10 poin dimana yang paling baik mempunyai skor 12 dan yang paling kecil mempunyai skor 7 .

\section{Hubungan variabel bebas dan variabel luar dengan variabel terikat}

Adapun hasil analisis variabel pelatihan, ketersediaan RDT, umur, masa kerja dan pendidikan dengan kinerja bidan dalam deteksi dini kasus malaria kehamilan dapat dilihat pada tabel.

Tabel 3. Perbandingan skor kinerja bidan dalam deteksi dini kasus malaria kehamilan berdasarkan variabel pelatihan daan ketersediaan RDT

\begin{tabular}{|c|c|c|c|c|c|c|}
\hline \multirow{2}{*}{ Variabel } & \multirow[b]{2}{*}{$\mathrm{n}$} & \multirow[b]{2}{*}{ Mean \pm SD } & \multicolumn{2}{|c|}{ Skor Kinerja } & \multirow[b]{2}{*}{$\mathrm{t}$} & \multirow[b]{2}{*}{$\mathrm{p}$} \\
\hline & & & Beda Rerata & $95 \% \mathrm{Cl}$ & & \\
\hline \multicolumn{7}{|l|}{ Pelatihan } \\
\hline Pernah & 47 & $11,1 \pm 1,12$ & \multirow{2}{*}{2,2} & \multirow{2}{*}{$1,71-2,51$} & \multirow{2}{*}{10,47} & \multirow{2}{*}{$0,000 *$} \\
\hline Belum Pernah & 98 & $8,9 \pm 1,14$ & & & & \\
\hline \multicolumn{7}{|c|}{ Ketersediaan RDT } \\
\hline Cukup & 48 & $10,7 \pm 1,19$ & \multirow{2}{*}{1,5} & \multirow{2}{*}{$1,01-1,94$} & \multirow{2}{*}{6,25} & \multirow{2}{*}{$0,000 *$} \\
\hline Tidak Cukup & 97 & $9,2 \pm 1,40$ & & & & \\
\hline
\end{tabular}

Keterangan: $p=p$-value $(*=$ signifikan $p<0,05)$

Kinerja deteksi dini kasus malaria kehamilan pada bidan yang telah mendapatkan pelatihan lebih tinggi daripada bidan yang belum mendapatkan pelatihan dengan perbedaan 2 poin (95\% $\mathrm{Cl}=1,71-2,51)$ sehingga dapat disimpulkan kinerja deteksi dini kasus malaria kehamilan pada bidan yang telah mendapatkan pelatihan lebih baik daripada bidan yang belum mendapatkan pelatihan.
Kinerja deteksi dini kasus malaria kehamilan pada bidan yang yang ketersediaan RDT cukup lebih tinggi daripada bidan yang ketersediaan RDT tidak cukup dengan perbedaan 1 poin (95\% $\mathrm{Cl}=1,01-1,94)$ sehingga dapat disimpulkan kinerja deteksi dini kasus malaria kehamilan pada bidan yang ketersediaan RDT cukup lebih baik daripada bidan ketersediaan RDT tidak cukup. 
Tabel 4. Perbandingan skor kinerja bidan dalam deteksi dini kasus malaria kehamilan berdasarkan variabel pendidikan

\begin{tabular}{ccccccc}
\hline \multirow{2}{*}{ Variabel } & \multicolumn{7}{c}{ Skor Kinerja } \\
\cline { 2 - 6 } & $\mathrm{n}$ & Mean \pm SD & Beda Rerata & $95 \% \mathrm{Cl}$ & $\mathrm{t}$ & $\mathrm{p}$ \\
\hline Pendidikan & & & & & \\
Tinggi & 95 & $9,9 \pm 1,27$ & 0,7 & $0,18-1,20$ & 2,69 & $0,007^{*}$ \\
Rendah & 50 & $9,2 \pm 1,79$ & & & & \\
\hline
\end{tabular}

Keterangan: $p=p$-value $(*=$ signifikan $p<0,05)$

Skor kinerja deteksi dini kasus malaria kehamilan pada bidan dengan pendidikan tinggi lebih besar dibandingkan bidan dengan pendidikan rendah dengan perbedaan 1 poin dan $95 \% \mathrm{Cl}=(0,18-1,20)$ dimana secara statistik dan praktis terdapat perbedaan yang bermakna, sehingga dapat disimpulkan kinerja deteksi dini kasus malaria kehamilan pada bidan dengan pendidikan tinggi lebih baik daripada bidan dengan pendidikan rendah.

Tabel 5. Korelasi Pearson kinerja dengan umur dan masa kerja

\begin{tabular}{cccc}
\hline \multirow{2}{*}{ Variabel } & \multicolumn{3}{c}{ Skor Kinerja } \\
\cline { 2 - 4 } & $\mathrm{R}$ & $\mathrm{R}^{2}$ & $\mathrm{p}$ \\
\hline Umur & $-0,10$ & 0,01 & 0,221 \\
Masa Kerja & $-0,13$ & 0,02 & 0,100 \\
\hline
\end{tabular}

Hasil analisis korelasi Pearson pada tabel menunjukkan bahwa antara variabel umur dengan kinerja deteksi dini kasus malaria kehamilan secara statistik dinyatakan tidak bermakna karena $p>0,05(p=0,221)$. Hal ini menunjukkan bahwa tidak ada hubungan antara umur dengan kinerja deteksi dini kasus malaria kehamilan. Secara praktis menunjukkan hubungan yag negatif dimana semakin bertambahnya umur bidan malah makin berkurang kinerja bidan tersebut $(r=-0,10)$.
Berdasarkan analisis juga menunjukkan bahwa secara statistik antara variabel masa kerja dengan kinerja deteksi dini kasus malaria kehamilan tidak mempunyai hubungan dengan nilai $p=0,100$, artinya bawa tidak ada hubungan antara masa kerja dengan kinerja deteksi dini kasus malaria kehamilan. Tetapi secara praktis terlihat ada hubungan negatif dimana dengan semakin lama masa kerja bidan maka semakin menurun kinerja bidan tersebut $(r=-0,13)$.

Tabel 6. Analisis perbandingan skor antara pelatihan dengan umur dan masa kerja

\begin{tabular}{crrrrrrr}
\hline \multirow{2}{*}{ Variabel } & \multicolumn{2}{c}{ Pelatihan } & & & & \\
& \cline { 2 - 3 } & \multicolumn{1}{c}{ Pernah } & Belum pernah & \multirow{2}{*}{$\begin{array}{c}\text { Beda } \\
\text { Rerata }\end{array}$} & $95 \% \mathrm{Cl}$ & $\mathrm{t}$ & $\mathrm{p}$-value \\
\cline { 2 - 3 } & \multicolumn{1}{c}{ Mean \pm SD } & Mean \pm SD & & & & \\
\hline Umur & $29,04 \pm 5,41$ & $28,21 \pm 2,80$ & 0,82 & $-0,51-2,17$ & 1,21 & 0,226 \\
Masa kerja & $6,59 \pm 3,84$ & $6,26 \pm 2,21$ & 0,33 & $-0,66-1,32$ & 0,65 & 0,513 \\
\hline
\end{tabular}


Analisis bivariabel antara variabel pelatihan dengan umur dan masa kerja terdapat perbedaan rerata skor umur pada bidan yang yang telah mendapatkan pelatihan dengan yang belum mendapatkan pelatihan yaitu 0,8 tahun $(95 \%$ $\mathrm{Cl}-0,51-2,17)$ dan terdapat perbedaan rerata skor masa kerja pada bidan yang yang telah mendapatkan pelatihan dengan yang belum mendapatkan pelatihan yaitu sebesar 0,3 tahun (95\% Cl -0,66-1,32). Secara statistik maupun praktis perbedaan tersebut dinyatakan tidak bermakna sehingga dapat disimpulkan bahwa variabel umur dan masa kerja tidak berhubungan dengan variabel pelatihan.

Tabel 7. Analisis perbandingan skor antara ketersediaan RDT dengan umur dan masa kerja

\begin{tabular}{|c|c|c|c|c|c|c|}
\hline \multirow{3}{*}{ Variabel } & \multicolumn{2}{|c|}{ Ketersediaan RDT } & \multirow{3}{*}{$\begin{array}{l}\text { Beda } \\
\text { Rerata }\end{array}$} & \multirow{3}{*}{$95 \% \mathrm{Cl}$} & \multirow{3}{*}{$\mathrm{t}$} & \multirow{3}{*}{$p$-value } \\
\hline & Cukup & Tidak Cukup & & & & \\
\hline & Mean $\pm S D$ & Mean $\pm S D$ & & & & \\
\hline Umur & $29,00 \pm 5,06$ & $28,22 \pm 3,07$ & 0,77 & $-0,56-2,11$ & 1,13 & 0,256 \\
\hline Masa kerja & $6,56 \pm 3,61$ & $6,28 \pm 2.37$ & 0,28 & $-0,70-1,27$ & 0,56 & 0,572 \\
\hline
\end{tabular}

Analisis bivariabel antara variabel ketersediaan RDT dengan umur dan masa kerja terdapat perbedaan rerata skor umur pada bidan yang ketersediaan RDT cukup dengan yang ketersediaan RDT tidak cukup yaitu 0,8 tahun dengan $95 \% \mathrm{Cl}-0,56-2,11)$ dan terdapat perbedaan skor masa kerja pada bidan yang ketersediaan RDT cukup dengan yang ketersediaan RDT tidak cukup yaitu sebesar 0.3 tahun dengan $95 \% \mathrm{Cl}-0,70-1,27$. Secara statistik maupun praktis perbedaan tersebut dinyatakan tidak bermakna sehingga dapat disimpulkan bahwa variabel umur dan masa kerja tidak berhubungan dengan variabel ketersediaan RDT.

Tabel 8. Analisis hubungan antara pendidikan dengan pelatihan dan ketersediaan RDT

\begin{tabular}{|c|c|c|c|c|c|c|c|}
\hline \multirow{3}{*}{ Variabel } & \multicolumn{4}{|c|}{ Pendidikan } & \multirow{3}{*}{$x^{2}$} & \multirow{3}{*}{$\mathrm{p}$} & \multirow{3}{*}{$95 \% \mathrm{Cl}$} \\
\hline & \multicolumn{2}{|c|}{ Tinggi } & \multicolumn{2}{|c|}{ Rendah } & & & \\
\hline & $\mathrm{n}$ & $\%$ & $\mathrm{~N}$ & $\%$ & & & \\
\hline \multicolumn{8}{|c|}{ Pelatihan } \\
\hline Pernah & 26 & 27,4 & 69 & 72,6 & \multirow{2}{*}{3,20} & \multirow{2}{*}{0,074} & \multirow{2}{*}{$0,41-1,03$} \\
\hline Tidak pernah & 21 & 42,0 & 29 & 58,0 & & & \\
\hline \multicolumn{8}{|l|}{ Ketersediaan RDT } \\
\hline Cukup & 29 & 30,5 & 19 & 38,0 & \multirow{2}{*}{0,83} & \multirow{2}{*}{0,363} & \multirow{2}{*}{$0,50-1,28$} \\
\hline Tidak cukup & 66 & 69,5 & 31 & 62,0 & & & \\
\hline
\end{tabular}

Dari tabel diatas menunjukkan bahwa tidak ada hubungan yang bermakna antara variabel pendidikan dengan variabel pelatihan dengan nilai $p=0,074$ dan $95 \% \mathrm{Cl}$ 0,41- 1,03. Dan tabel diatas juga menunjukkan bahwa tidak ada hubungan yang bermakna antara variabel pendidikan dengan variabel ketersediaan RDT dengan nilai $p=0,363$ dan $95 \%$ CI $0,50-1,28$

\section{Hubungan variabel bebas dan variabel luar yang berhubungan dengan variabel terikat}

Untuk variabel bebas dan variabel luar yang berhubungan dengan variabel terikat 
dilakukan analisis multivariabel, dalam hal I ini menggunakan regresi linear ganda. Variabel yang dianalisis pada analisis multivariabel ini adalah variabel bebas dan variabel luar yang mempunyai nilai $p<0,05$.

Tabel 9. Analisis regresi linear antara pelatihan dan ketersediaan RDT dengan kinerja bidan dalam deteksi dini kasus malaria kehamilan dengan mengikutsertakan variabel pendidikan

\begin{tabular}{|c|c|c|c|c|}
\hline \multirow{2}{*}{ Variabel } & \multicolumn{2}{|c|}{ Model 1} & \multicolumn{2}{|c|}{ Model 2} \\
\hline & Koofisien & $95 \% \mathrm{Cl}$ & Koofisien & $95 \% \mathrm{Cl}$ \\
\hline Pelatihan & $1,89 *$ & $(1,52-2,25)$ & $2,04 *$ & $(1,72-2,36)$ \\
\hline \multicolumn{5}{|l|}{ Pernah } \\
\hline \multicolumn{5}{|l|}{ Belum Pernah } \\
\hline Ketersediaan RDT & $1,10^{*}$ & $(0,73-1,46)$ & $1,15^{*}$ & $(0,83-1,46)$ \\
\hline \multicolumn{5}{|l|}{ Cukup } \\
\hline \multicolumn{5}{|l|}{ Tidak Cukup } \\
\hline Pendidikan & & & $1,08^{*}$ & $(0,77-1,39)$ \\
\hline \multicolumn{5}{|l|}{ Tinggi } \\
\hline \multicolumn{5}{|l|}{ Rendah } \\
\hline Konstanta & \multicolumn{2}{|c|}{8,69} & \multicolumn{2}{|c|}{7,92} \\
\hline$R^{2}$ & \multicolumn{2}{|c|}{0,55} & \multicolumn{2}{|c|}{0,66} \\
\hline $\mathrm{N}$ & \multicolumn{2}{|c|}{145} & \multicolumn{2}{|c|}{145} \\
\hline
\end{tabular}

Dengan menggunakan analisis multivariavel didapatkan variabel pelatihan dan ketersediaan RDT berhubungan dengan kinerja deteksi dini kasus malaria kehamilan. Hasil analisis menunjukkan pelatihan memiliki koefisien regresi sebesar 1,89 dan ketersediaan RDT sebesar 1,10 dengan nilai $p$ value lebih kecil dari 0 . Hal ini menunjukkan bahwa dengan pernah mengikuti pelatihan maka dapat meningkatkan kinerja bidan sebesar 2 poin dan dengan ketersediaan RDT yang cukup maka dapat meningkatkan kinerja bidan dalam sebesar 1 poin. Model ini memilliki nilai $R^{2}$ sebesar 0,55 berarti pelatihan dan ketersediaan RDT dapat menyebabkan perubahan kinerja bidan dalam deteksi dini kasus malaria kehamilan sebesar $55 \%$.

Setelah dikontrol dengan variabel pendidikan ternyata variabel pelatihan memiliki koefisien regresi sebesar 2,04 dan ketersediaan RDT sebesar 1,15. Hal ini menunjukkan bahwa dengan pernah mengikuti pelatihan maka dapat meningkatkan kinerja bidan sebesar 2 poin dan dengan ketersediaan RDT yang cukup maka dapat meningkatkan kinerja bidan sebesar 1 poin setelah dikontrol dengan variabel pendidikan. Nilai koefisien ini menjadi meningkat bila dibandingkan dengan koefisien perlakuan sebelum dikontrol dengan pendidikan. Model ini memiliki nilai $R^{2}$ sebesar 0,66 berarti pelatihan dan ketersediaan RDT dapat menyebabkan perubahan kinerja bidan dalam deteksi dini kasus malaria kehamilan sebesar $66 \%$ setelah dikontrol dengan variabel pendidikan. Perubahan ini menjadi lebih besar bila dibanding dengan model 1 yang belum dikontrol dengan variabel pendidikan. 
1. Hubungan pelatihan dengan kinerja bidan desa dalam deteksi dini kasus malaria kehamilan

Kinerja deteksi dini kasus malaria kehamilan pada bidan yang telah mendapatkan pelatihan lebih tinggi daripada bidan yang belum mendapatkan pelatihan. Terdapat perbedaan sebesar 2 poin dengan $95 \% \mathrm{Cl}=1,71-2,51$ yang terbukti signifikan secara statistik dan praktis. Kinerja petugas kesehatan di Tanzania dalam upaya deteksi malaria perlu diimbangi dengan pelatihan yang sesuai. ${ }^{4}$ Tenaga kesehatan merupakan pilar dalam memberikan pelayanan kesehatan berkualitas bagi masyarakat berfokus pada peningkatan sumber daya manusia melalui pelatihan dan penguatan kinerja yang benar. Hal-hal tersebut diatas mempengaruhi petugas kesehatan dalam memberikan pelayanan kesehatan yang maksimal. ${ }^{4}$

Pelatihanadalahsuatukegiatan pembelajaran dalam upaya meningkatkan pengetahuan dan ketrampilan untuk memperbaiki kinerja pekerja pada suatu pekerjaan tertentu yang menjadi tanggung jawabnya atau berkaitan dengan pekerjaan menjadi lebih baik dan efektif. ${ }^{5} \mathrm{Hal}$ ini tentu akan berpengaruh positif terhadap kinerja karyawan yang bersangkutan. ${ }^{6}$

\section{Hubungan ketersediaan RDT dengann} kinerja bidan desa dalam deteksi dini kasus malaria kehamilan

Dari hasil analisis bivariabel didapatkan bahwa kinerja deteksi dini kasus malaria kehamilan pada bidan yang yang ketersediaan RDT cukup lebih tinggi daripada bidan yang ketersediaan RDT tidak cukup. Terdapat perbedaan sebesar 1 poin dengan $95 \% \mathrm{Cl}=1,01$ 1,94 yang terbukti signifikan secara statistik dan praktis. Lingkungan dan alat mempengaruhi kinerja dari bidan. ${ }^{7}$ Peralatan adalah sarana yang dapat membantu manusia dalam melakukan pekerjaan dengan lebih berkeahlian, efisien atau efektif jika seorang manusia mengendalikannya. ${ }^{8}$

Ketersediaan sarana pelayanan sebagai salah satu faktor pendukung yang tidak boleh dilupakan yang merupakan sarana atau alat dalam pelaksanaan tugas pelayanan. Sarana pelayanan yang dimaksud disini adalah segala jenis peralatan, perlengkapan kerja dan fasilitas lain yang berfungsi sebagai alat utama/pembantu dalam pelaksanaan pekerjaan. ${ }^{9}$ Ketersediaan sarana dan prasarana berpengaruh terhadap kinerja individu. ${ }^{10}$

\section{Hubungan umur dengan kinerja bidan desa dalam deteksi dini kasus malaria kehamilan}

Dari analisis bivariabel korelasi Pearson antara variabel umur dengan kinerja deteksi dini kasus malaria kehamilan secara statistik dinyatakan tidak bermakna karena $p>0,05$ ( $r=-$ $0,10, p=0,221)$. Hal ini menunjukkan bahwa tidak ada hubungan antara umur dengan kinerja deteksi dini kasus malaria kehamilan. Hal ini sesuai dengan dengan penelitian tentang faktorfaktor yang berhubungan dengan kinerja bidan desa di Kabupaten Pati yang menyebutkan bahwa umur tidak berhubungan dengan kinerja. ${ }^{11}$ Hasil ini juga sejalan dengan survey di Amerika Serikat yang menunjukkan bahwa 93\% pekerja usia lanjut sama baiknya dengan usia muda. ${ }^{12}$

Usia harus mendapat perhatian karena akan mempengaruhi kondisi fisik, mental, kemampuan kerja dan tanggung jawab seseorang. Karyawan muda umumnya mempunyai fisik yang lebih kuat, dinamis, kreatif, tetapi cepat bosan, kurang bertanggung jawab, cenderung absensi, turn overnya tinggi. Karyawan lebih tua kondisi fisiknya kurang, tetapi bekerja ulet dan bertanggung jawab besar, absensi dan turn overnya rendah. ${ }^{13}$ Sedangkan umur yang lebih muda akan lebih agresif dan relatif lebih produktif. ${ }^{14}$ 
4. Hubungan masa kerja dengan kinerja bidan desa dalam deteksi dini kasus malaria kehamilan

Dari analisis bivariabel korelasi Pearson antara variabel masa kerja dengan kinerja deteksi dini kasus malaria kehamilan secara statistik dinyatakan tidak bermakna karena $p>$ $0,05(r=-0,13, p=0,100)$. Hal ini menunjukkan bahwa tidak ada hubungan antara masa kerja dengan kinerja deteksi dini kasus malaria kehamilan. Kecenderungan ini mendukung penelitian yang dilakukan tentang analisis faktor-faktor yang berhubungan dengan kinerja bidan di desa di Kabupaten Pati bahwa masa kerja tidak berhubungan dengan kinerja bidan di desa. ${ }^{11}$ Lama kerja biasanya dikaitkan dengan waktu mulai bekerja dengan umur pada saat ini, masa kerja berkaitan erat dengan pengalamanpengalaman yang didapat selama dalam menjalankan tugas. Masa kerja bidan di desa meskipun rata-rata 9 tahun tetapi belum dapat untuk menjelaskan bahwa bidan yang sudah lama bekerja akan lebih meningkat kinerjanya. Masa kerja tidak berhubungan dengan kinerja seseorang, semakin senior seorang pekerja bukanlah berarti akan lebih baik kinerjanya dibandingkan pada pekerja yang senioritasnya lebih rendah. Banyak studi tentang hubungan senioritas karyawan dan produktifitas. Meskipun prestasi kerja seseorang itu bisa ditelusuri dari prestasi kerja sebelumnya, tetapi sampai saat ini belum dapat diambil kesimpulan yang meyakinkan antara kedua variabel tersebut. Pengalaman kerja yang sudah lama, tetap belum menjamin bahwa mereka lebih produktif daripada karyawan-karyawan yang belum lama bekerja di situ. ${ }^{15}$ Tidak ada alasan untuk meyakini bahwa orang-orang yang lebih lama berada pada suatu pekerjaan akan lebih produktif daripada mereka yang senioritasnya lebih rendah. ${ }^{16}$

\section{Hubungan pendidikan dengan kinerja bidan desa dalam deteksi dini kasus malaria kehamilan}

Kinerja deteksi dini kasus malaria kehamilan pada bidan dengan pendidikan tinggi lebih besar dibandingkan bidan dengan pendidikan rendah. Perbedaan reratanya sebesar 1 poin dengan $95 \% \mathrm{Cl}=-0,18-1,20$ yang terbukti signifikan secara statistik dan praktis. Tingkat pendidikan seseorang akan mempengaruhi peningkatan kemampuan pengetahuan dan keterampilan seorang petugas. ${ }^{17}$ Pendidikan mempengaruhi kinerja seseorang dalam berkerja. ${ }^{18}$ Semakin tinggi pendidikan semakin tinggi produktivitas kerja. ${ }^{19}$ Pendidikan merupakan salah satu kebutuhan dasar manusia yang diperlukan untuk pengembangan diri. Semakin tinggi tingkat pendidikan, semakin mudah mereka menerima serta mengembangkan pengetahuan dan teknologi, sehingga akan meningkatkan produktivitas yang pada akhirnya akan meningkatkan kesejahteraan keluarga agar termotivasi untuk meningkatkan kinerjanya. ${ }^{20}$

\section{KESIMPULAN DAN SARAN}

Berdasarkan analisis dan pembahasan yang telah dikemukakan dalam penelitian ini, maka dapat diambil suatu kesimpulan bahwa:

1. Kinerja deteksi dini kasus malaria kehamilan pada bidan yang telah mendapatkan pelatihan lebih baik daripada bidan yang belum mendapatkan pelatihan.

2. Kinerja deteksi dini kasus malaria kehamilan pada bidan yang ketersediaan RDT cukup lebih baik daripada bidan ketersediaan RDT tidak cukup.

\section{DAFTAR PUSTAKA}

1. Kementerian Kesehatan RI. Indeks Pembangunan Kesehatan Masyarakat. Jakarta: Badan Litbang Kesehatan Kemenkes RI; 2010. 
2. Bappenas. Laporan pencapaian tujuan pembangunan milenium Indonesia 2010. Jakarta: Kementerian PPN/Bappenas; 2010.

3. Bagian P2PL Dinkeskab Bengkulu Tengah. Laporan jumlah penderita malaria. Dinkes Kabupaten Bengkulu Tengah 2013.

4. Rachel MN, Tanya, M. C \& Ib, B. C. Improving motivation among primary health care workers in Tanzania; a health worker perspective. Human resources for health, 4. . 2006.

5. Gomes FC. Manajemen Sumber Daya Manusia. Yogyakarta2000.

6. Mangkunegara. AP. Evaluasi Kinerja SDM. RA, editor. Bandung2006.

7. Fort AL, Voltero L. Factors affecting the performance of maternal health care providers in Armenia. Human resources for health. 2004;2(8):1-11.

8. Sota. Pengembangan Sumber Daya Manusia. Surabaya Airlangga University Press; 2003.

9. Gitosudarmo IdS, Nyoman, . Perilaku Keorganisasian Edisi pertama cetakan ke 2. Yogyakarta: BPFE 2000.

10. Gibson JL, Ivancevich JM. Organisasi Perilaku, Struktur, Proses Jakarta: Airlangga. 1996.
11. Masnuchaddin S. Faktor-Faktor Yang Berhubungan Dengan Kinerja Bidan Di Desa Dalam Pelayanan Antenatal Di Kabupaten Pati, . Yogyakarta: Universitas Gadjah Mada; 1998.

12. Budioro B. Pengantar Administrasi Kesehatan Masyarakat,. Semarang: Badan Penerbit Universitas Diponegoro 2002.

13. Samsudin S. .Manajemen Sumber Daya Manusia. Bandung: Pustaka Setia; 2006.

14. Notoatmodjo S. Pengantar perilaku kesehatan. Jakarta: FKM-UI; 1995.

15. Siagian SP. Manajemen sumber daya manusia. Jakarta: Bumi Aksara; 2008.

16. Robbins SP. Perilaku Organisasi : Konsep, Kontroversi dan Aplikasi. Jilid 1 (Edisi bahasa Indonesia) Jakarta: PT Prenhallindo, ; 2001.

17. Notoatmodjo S. Promosi kesehatan teori dan aplikasi. Jakarta: Rineka Cipta. 2005:52-4.

18. Hersey P, Blanchard KH, Johnson DE. Management of organizational behavior. 1992.

19. Arfrida. Ekonomi Sumber Daya Manusia. Jakarta: Ghalia Indonesia; 2003.

20. Grossmann M. The Human Capital Model of The Demand for Health Cambridge: National Bureau of Economic Research. 1999. 